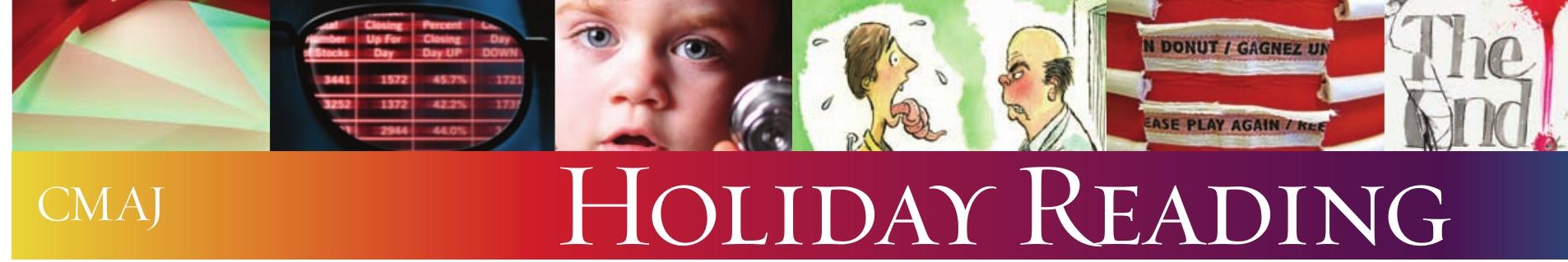

IN OTHER WORDS

\title{
Petit manuel de traduction à l'usage des enfants mourants
}

Claude Cyr MD MSc

\begin{tabular}{|ll|}
\hline Petit manuel de traduction à l'usage des enfants mourants \\
\hline Adulte & Enfant \\
\hline Douleur & d'où leur \\
\hline Morphine et le fentanyl? & mort fine éléphant à nil ? \\
\hline Acetami... & assez d'ami(e)s? \\
\hline Métastase et tes ganglions & $\begin{array}{l}\text { Mets ta tasse et tes dents de lion } \\
\text { (beau costume d'Halloween, en passant) }\end{array}$ \\
\hline ecchymoses & eskimoses* \\
\hline Cancer du sang & quand sert du cent? \\
\hline LLA & elle est là \\
\hline Tumeur & tu meurs? \\
\hline Mourir & Mou rire \\
\hline Chagrin & Chat grain \\
\hline Deuil & d'oeil (pour oeil, dent pour dent) \\
\hline *Femme Innuit. & \\
\hline
\end{tabular}

Intérêts concurrents : Aucun déclaré.

Correspondance : $\mathrm{D}^{\mathrm{r}}$ Claude Cyr, claude.cyr @usherbrooke.ca

Affiliations : Claude Cyr est Pédiatre Professeur titulaire, Faculté de Médecine et des Sciences de la Santé Université de Sherbrooke, Sherbrooke, Que.

CMAJ 2011. DOI:10.1503/cmaj.110785

\section{Holiday reading: thanks and more goodies online}

CMAJ's call for entertaining Holiday Reading fare attracted a cornucopia of tantalizing submissions, resulting in some very difficult decisions. Thank you to our esteemed panel of humour aficionados, Sarah Currie, Erin Driscoll, Jesse Elliot, Diane Kelsall, Wayne Kondro and Leesa Sullivan, and to our talented designer Carole Lalonde. And a special thank you to everyone who submitted a manuscript.

For more holiday reading, please go online and check out:

- Elevators of stairs? Have you ever wondered which is faster on shorter jaunts? Our intrepid researchers reveal all in this fast-paced research.

- The art of presenting The consummate how-not-to instruction aid, to ensure that you never get asked to present again. Ever. Invaluable reading for young physicians.

- "The first thing we do, let's kill all the actuaries" Shakespeare said it first, but our author adds a contemporary twist in the context of our aging population. Don't be a stat.

We wish you an hour or so of entertaining reading over the holidays. - Barbara Sibbald, Deputy Editor, Humour, CMAJ 